\title{
The Effect of Adrenomedullin (ADM) on Tyrosine Hydroxylase (TH) Enzyme Activity and Blood Pressure in Cold Exposed Rats
}

\author{
SENGUL YUKSEL AND MUHITTIN YUREKLI* \\ Department of Medical Biology and Genetics, Inonu University, School of Medicine, Malatya 44069, TURKEY \\ *Department of Molecular Biology, Science and Art Faculty, Inonu University, Malatya 44069, TURKEY
}

\begin{abstract}
It is known that, under stress conditions the hypothalamo-pituitary-adrenal (HPA) axis is stimulated and catecholamine production is increased. Adrenomedullin (ADM) is a novel peptide that elicits a long-vasorelaxation, and participates in blood pressure regulation via different mechanisms. In the present study, we investigated the administration of ADM on tyrosine hydroxylase (TH) enzyme activity in cold exposed rats. Four groups of SpragueDawley rats were studied for their TH enzyme activity in the adrenal medulla and hypothalamus. In addition to measuring blood pressure in these rats, TH enzyme activity in both the adrenal medulla and hypothalamus were examined in four groups of Sprague-Dawley rats: animals exposed to room temperature and cold stress $\left(8^{\circ} \mathrm{C}, 48 \mathrm{~h}\right)$, and rats injected with $\operatorname{ADM}(1.0 \mathrm{nmol} / \mathrm{kg}$, i.v. $)$ alone and/or together with cold stress. TH activity was shown to be increased in cold treated groups and decreased in ADM and ADM + cold stress group. Our findings appear to suggest that external ADM application caused an opposite effect on the same system in rats, decreasing the activity of tyrosine hydroxylase (TH) enzyme activity. Furthermore, externally applied ADM was shown to produce its expected hypotensive effect in coldstressed rats. Our results suggest that a possible explanation for the effects of ADM is that, the uptake of ADM under cold stress may effect TH activity in studied tissues.
\end{abstract}

Keywords: Adrenomedullin, Cold Stress, Rat, Tyrosine Hydroxylase, Blood Pressure

(Endocrine Journal 50: 553-559, 2003)

ALL living organisms respond to stress changes in the environment in various ways. The stress system has two major divisions: central and peripheral. The central division is represented by the medullary and hypothalamic nuclei whose neurons release corticotropin releasing factor (CRF), catecholamines, and arginine-vasopressin. The peripheral division is represented by the hypothalamic-pituitary-adrenal (HPA) axis and the autonomic system. Regulation of the stress system is extremely complicated and occurs at multiple levels. Activation of the stress system leads to behavioral and peripheral changes to improve the ability of the organism to adjust homeostasis and increase its chances for survival [1].

Received: November 20, 2002

Accepted: April 8, 2003

Correspondence to: Dr. Sengul YUKSEL, Department of Medical Biology and Genetics, Inonu University, School of Medicine, Malatya 44069, TURKEY
Exposure to extreme environments such as heat and cold is a form of stress to be endured by all organisms. Recently, animal models are being developed utilizing cold application to study the physiopathologic mechanisms and sequelae of stress. The signs of gross pathology of cold on the body are variable and have been reviewed elsewhere [2]. The physiological components of stress response to cold are metabolic, circulatory and hormonal. Different physical stressors show a somewhat specific neuroendocrine response profile, The response of the pituitary-adrenal (PA) and sympatho-medullo-adrenal axes, however, are common to almost all stressors $[3,4]$. Cold stress enhances the synthesis and release of catecholamines in the peripheral as well as in the brain, adrenal medulla and heart $[5,6]$. The most pronounced alterations occur in the synthesis and release of tyrosine hydroxylase (TH), the initial and rate-limiting enzyme in catecholamine biosynthesis [7].

Adrenomedullin (ADM), a recently discovered 52- 
amino-acid peptide hormone, circulates in the plasma at low picomolar levels in man. Although initially isolated from human pheochromacytoma tissue, ADM mRNA was observed in the adrenal medulla, heart ventricle, kidney, lung and pancreas $[8,9]$. In addition, ADM binding sites were observed in the rat brain, including the hypothalamus $[10,11]$.

Animal studies and studies in vitro indicate that ADM has diverse biological actions, including vasodilatation, natriuresis and diuresis, and positive inotropism as well as antiproliferative effects [11-13]. It has been reported that ADM is associated with some diseases [14-16]. The vasodilator effects of ADM has been suggested previously to be mediated via CGRP receptors, coupled to the accumulation of intracellular cAMP, release of nitric oxide and increased intracellular $\mathrm{Ca}^{2+}$ concentrations or activated phospholipase C [17-19].

The endocrine effects of ADM have been shown to be mediated by inhibiting ACTH release [20], aldosterone production [21, 22], corticosterone [23] and cortisol [24] secretion in various species. Moreover, ADM appears to be co-secreted with catecholamines in response to nicotinic stimulation $[25,26]$. The role of adrenal catecholamines in mediating pressor responses to human ADM has also been investigated. Following bilateral adrenalectomi pressor responses to hADM have been shown to be significantly reduced compared with control responses obtained before adrenalectomy [27].

$\mathrm{ADM}$ and its receptor have been shown to be expressed in the central nervous system (CNS) and its cellular components [10, 28, 29]. The direct effects of ADM on sympathetic nerve activity in conscious rats have been observed and these studies are consistant with the observations reported by Takekoshi and colleagues [30], who showed that in anesthetized rats, icv ADM induces an increase in preganglionic sympathetic discharge. The electrical activity of neurons within the area postrema of the medulla are directly affected by ADM in brain slice preparations [31].

Experimental data suggest that ADM interacts at various levels within the renin-angiotensin-aldosterone (RAS) system and the hypothalamic-pituitary-adrenal (HPA) axis. In the present study, we aimed to investigate a rat model for the future study of biological effects of cold stress including homeostatic response via ADM to focus on vascular, endocrine, renal and CNS aspects.

\section{Materials and Methods}

Twenty seven male Sprague-Dawley rats (3 months old, 180-220 g) were housed individually under diurnal lighting conditions (12-12 h) with free access to food and water. For the study, rats were divided into four experimental groups; namely, a control group $(n=7)$, group receiving cold stress only $(n=6)$, group receiving only ADM at room temperature $(n=8)$ and a group receiving ADM and cold stress $(n=6)$. Animals in the cold-stress groups were subjected to $48 \mathrm{~h}$ at $8^{\circ} \mathrm{C}$.

Control and cold-stressed rats were anesthetized via an intraperitoneal injection of sodium pentobarbital $(50 \mathrm{mg} / \mathrm{kg})$. Rats were placed on a heated table to maintain body temperature at $36-37^{\circ} \mathrm{C}$. The jugular vein was cannulated for drug administration. Systemic blood pressure was monitered continuously from the carotid artery by a Harvard model 50-8652 transducer and displayed on a Harvard Universal Penrecorder together with standard lead-1 ECG. The rats were left for $45 \mathrm{~min}$ after surgery to allow for equilibration, after which rat adrenomedullin (purchased from Phoenix Pharmaceuticals Inc. USA) $(1.0 \mathrm{nmol} / \mathrm{kg}$, dissolved in saline) was injected intravenously $(n=8)$. Control animals received an equal volume of saline $(0.09 \% \mathrm{NaCl} \mathrm{w} / \mathrm{v}$. dissolved in distilled water $)$. Arterial blood pressure was measured in the cold-treated group, 15 and $0 \mathrm{~min}$ before and 2, 5, 10 and $30 \mathrm{~min}$ following ADM administration, at room temperature [32]. Average blood pressure was calculated as the sum of $40 \%$ of the systolic blood pressure and $60 \%$ of the diastolic blood pressure values.

Following the study, the rats were sacrificed and their adrenal glands and hypothalamus were removed quickly and immediately frozen by immersion in liquid nitrogen. In addition, adrenal and hypothalamus preparations were weighed and homogenized in $100 \mu \mathrm{l}$ of phosphate buffer $\left(2 \mathrm{mM} \mathrm{NaPO}_{4}, 0.2 \%\right.$ triton, $\mathrm{pH}$ 7.0). Protein was determined by the Bradford method [33]. TH activity was measured using a modification by Reinhard et al. [34].

Data were analyzed using statistical software programme (SPSS for Windows). Data were compared with normal controls using one-way analysis of variance (ANOVA) to determine if there were any significant differences amoung groups. Comparison of differences between groups was done by the least significant differences (protected t) tests. Significance 
was set at the $95 \%$ confidence limit. Results are shown as mean \pm S.D.

\section{Results}

To determine the effect of cold stress and ADM on catecholamine biosynthesis, TH activity was assayed in homogenates of adrenal medulla and hypothalamus following a 48-h cold exposure in ADM administrated rats. TH activity was significantly greater compared to that of ADM administrated animals (Table 1). TH activity was found to be significantly decreased in the adrenal medulla and hypothalamus and depended on ADM administration.

TH enzyme activity was significantly elevated in cold-stressed rats compared to controls. In the adrenal medulla, TH enzyme activities were $32.9 \pm 0.6 \mathrm{nmol}$ $/ \mathrm{mg} / \mathrm{h}, \quad 52.3 \pm 7.2 \mathrm{nmol} / \mathrm{mg} / \mathrm{h}, \quad 21.0 \pm 2.9 \mathrm{nmol} / \mathrm{mg} / \mathrm{h}$ and $37.4 \pm 1.8 \mathrm{nmol} / \mathrm{mg} / \mathrm{h}$ in control, cold exposed, ADM treated (room temperature) and ADM + coldstressed animals, respectively. There was a significant differencein the adrenal medulla $\mathrm{TH}$ activity between control animals and cold-stressed and ADM treated rats $(\mathrm{P}<0.05)$.

Similar to our aforementioned findings in the adrenal medulla, TH enzyme activity increased following a $48 \mathrm{~h}$ cold exposure in the hypothalamus, although it was not significant. TH activities were $50.4 \pm$ $4.1 \mathrm{nmol} / \mathrm{mg} / \mathrm{h}$ in control, $54.4 \pm 3.6 \mathrm{nmol} / \mathrm{mg} / \mathrm{h}$ in cold-exposed, $40.4 \pm 1.9 \mathrm{nmol} / \mathrm{mg} / \mathrm{h}$ in ADM treated and $46.2 \pm 2.4 \mathrm{nmol} / \mathrm{mg} / \mathrm{hr}$ in hypothalamus of ADM + cold-stress treated rats. There was a difference in hypothalamic $\mathrm{TH}$ activity between control and ADM treatment groups $(\mathrm{P}<0.05)$ (Table 1).

Fig. 1 shows the mean arterial blood pressure of control and study groups. Both before and after administration of ADM, the arterial blood pressure values of the rats were recorded during a 30 min time period. According to the results, the avarage arterial blood pressure in the control group were found to be $109.1 \pm 18.5 \mathrm{mmHg}$ (mean \pm S.D., $\mathrm{n}=7$ ). An intravenous injection of ADM caused a rapid, strong and long lasting hypotensive effect in both cold-stressed rats and in rats maintained at room temperature. When $\operatorname{ADM}(1.0 \mathrm{nmol} / \mathrm{kg})$ was injected intravenously, mean blood pressure was found to be $80.1 \pm 22.8 \mathrm{mmHg}$ (mean \pm S.D., $\mathrm{n}=8$ ) in the room temperature maintained group and $85.2 \pm 14.4 \mathrm{mmHg}$ (mean \pm S.D., $\mathrm{n}=6$ ) in the ADM treated + cold-stressed rats. There were no significant changes in the arterial blood pressures of cold-stressed rats $107.8 \pm 18.0 \mathrm{mmHg}$ (mean \pm S.D., $\mathrm{n}=6$ ) compared to controls $(\mathrm{P}<0.05)$ (Table 1).

\section{Discussion}

In the present study, we examined the effects of ADM administration on TH enzyme activity in the adrenal medulla and hypothalamus in response to cold exposure in rats. While doing a literature search, we found that the studies conducted to reveal the physiological sequelae of ADM response to stress have been conducted under several experimental conditions and thus variable results, which may seemingly be contradictory to interpret, have been obtained in different animal models. For instance the time-dependent regulation of ADM response to stress and its mechanisms at the cellular level in different end-organs remains, at present, unclear. The lack of clarity and variable results described to date regarding ADM responses to stress lead us to idea to study the cold induced stress response in a rat model. It has previously been suggested that $[35,36]$ cold, being a form of physiological stress, induces ADM release. However, the literature to date supports inferences rather than clear cut evidence to this concept.

Table 1. Tyrosine hydroxylase (TH) enzyme activities (nmol/mg/h) in the ADM and cold stressed rat application (mean \pm S.D.)

\begin{tabular}{lcccc}
\hline & Control & Cold stress & ADM & ADM + cold stress \\
\hline Adrenal medulla $(\mathrm{nmol} / \mathrm{mg} / \mathrm{h})$ & $32.9 \pm 0.6$ & $52.3 \pm 7.2^{\mathrm{a}}$ & $21.0 \pm 2.9^{\mathrm{a}}$ & $37.4 \pm 1.8$ \\
Hypothalamus $(\mathrm{nmol} / \mathrm{mg} / \mathrm{h})$ & $50.4 \pm 4.1$ & $54.4 \pm 3.6$ & $40.4 \pm 1.9^{\mathrm{b}}$ & $46.2 \pm 2.4$ \\
\hline
\end{tabular}

Means \pm SD are shown.

${ }^{a} \mathrm{p}<0.05$ compared to control and ADM + cold stressed groups.

${ }^{\mathrm{b}} \mathrm{p}<0.05$ compared to control and other groups. 


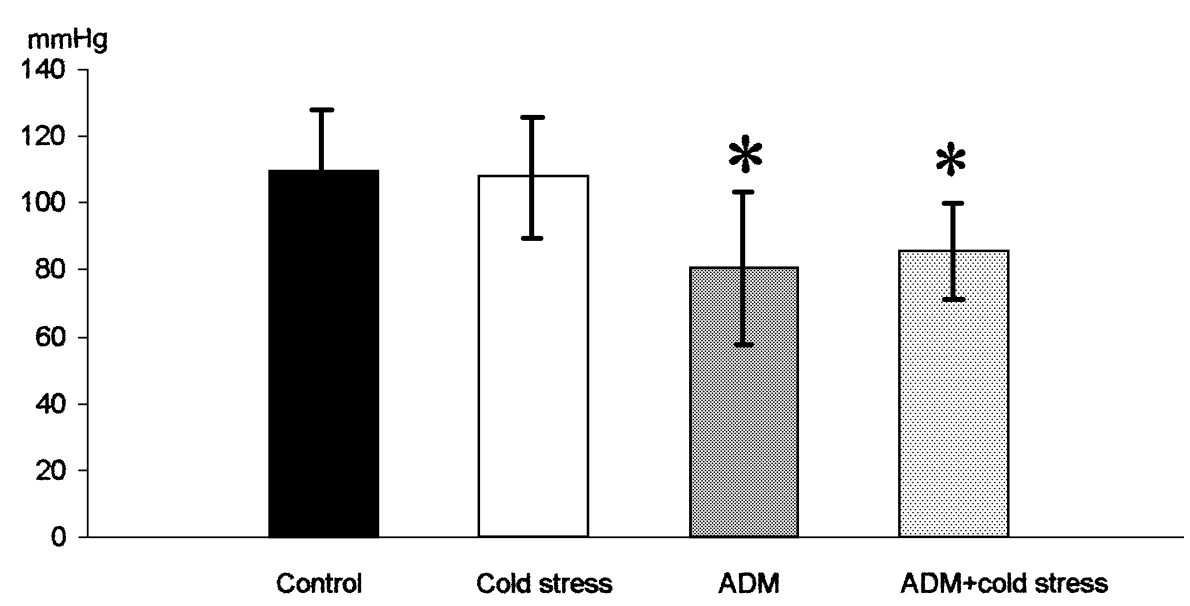

Fig. 1. The mean arterial blood pressure in control and study groups

ADM is involved in the regulation of the hypothalamo-neurohypophysial system, the HPA axis, and central autonomic functions. Ueta et al, [11] showed that ADM labelled cells were localized in the rat hypothalamus, including in the paraventricular and supraoptic nuclei, Morever, Ueta's group found that central ADM preferentially stimulates the secretion of oxytocin by activating hypothalamic oxytocinsecreting cells and may have an important role in salt appetite and body fluid homeostasis in rats. The synthesis of ADM is also actively regulated in both the cortex and medulla of the adrenal [37]. Much research effort has been focused on identifying a role for ADM in the adrenal gland. To date, no consistent effect on medullary catecholamine biosynthesis has been demonstrated.

Masada et al. [38] have investigated the effects of ADM and PAMP on the release of adrenal catecholamines in response to cholinergic stimuli in pentobarbital sodium-anesthetized dogs. They reported that PAMP, but not ADM, can act as an inhibitory regulator of adrenal catecholamine release. Okamura et al. [39] showed that ADM has the ability to inhibit adrenergic neuronal transmission in the peripheral vasculature. Champion et al. [27] reported that the release of catecholamines from the adrenal medulla in response to human ADM [15-22] does not depend on a cholinergic mechanism. These data are not in agreement with our studies showing that ADM possesses inhibitory effects on TH enzyme activity. Results from the present investigation showed that the administration of ADM decreases TH enzyme activity in the adrenal medulla and hypothalamus of the rat.

Chronic cold exposure is associated with a gradual increase in the activity of $\mathrm{TH}$, the key enzyme in catecholamine biosynthesis in the adrenal medulla and hypothalamus. Kanayama et al. [2] reported that significant increases were seen in plasma epinephrine, as well as serum insulin concentrations in rats that underwent localized cold stimulation. In our study, we found that TH enzyme activity increased in cold exposed animals. This appears to suggest that the ADM reduces the level of catecholamines. Acute stress is known to stimulate sympathetic activity as well as the HPA axis, which produces a significant increase in ADM levels in the pituitary gland, plasma and adrenal glands, all of which are key components of the HPA axis, These findings may suggest that $\mathrm{ADM}$ has a regulatory or protective role in countering HPA activation following a variety of physiological and psychological stressors $[4,40]$.

We investigated the effect of ADM on TH enzyme activity in cold exposed rats and the results of these experiments suggest that ADM has an inhibitory effect on TH enzyme activity and this effect also continues under cold stress conditions.

Several investigators have previously studied the effect of cold on blood pressure and hemodynamic parameters. In a study by Kato et al. [35], the function of the endothelium following cold storage at $4^{\circ} \mathrm{C}$ for $1,3,5$ and 7 days was investigated in a canine tibial perfusion model. Function was assesed in terms of changes in perfusion pressure, changes in the concentration of endothelin in the venous effluent from the perfused tibiae, adrenomedullin-induced vascular 
smooth muscle relaxation, and norepinephrine-induced pressor responses in the presence of acetylcholine, $\mathrm{N}(\mathrm{G})$-monomethyl-L-arginine acetate, or indomethacin. The literature indicates that some of the physiological molecules that participate in cold induced hypotensive responses to hypothermia including the effects of ADM and PAMP show hypotensive effects in anesthetized rats, but exhibit a different hypotensive mechanism. Binding sites for radiolabeled ADM have been demonsrated in all body tissues and organs where preproadrenomedullin gene is expressed [41], the greatest density being found in the heart, blood vessels and lungs. The observation of marked differences of ADM binding displacement by CGRP and amylin among different tissues and organs suggests regional variations in ADM receptor specificity. Together CGRP, CT, amylin and ADM have overlapping biological effects owing to their structures and cross-reactivity between receptors. Recently, it has also been shown that some cells express specific ADM receptors, but not CGRP receptors [42], con- trasting the notion that ADM receptors and CGRP receptors are a common subtype in many cell systems. There is also evidence that the expression level of $\mathrm{ADM}$ receptors and mediated second messenger cAMP levels are regulated by hormones like increased endothelin which also contribute to ADM response [43]. In a study by Edwards et al., alternative signal transduction pathways for ADM signalling have been shown to exist [44].

To our knowledge, this is the first report showing that ADM can decrease arterial blood pressure and TH enzyme activity in the adrenal medulla and hypothalamus in cold exposed rats. The results of our experiment suggest that ADM and the rate-limiting enzyme TH may play an important role in the continuity of homeostasis as antagonist substances. Further studies are needed to understand the exact role of ADM in response to cold exposure. Study of the stress response is a broad topic and our group intends to further investigate its mechanisms of regulation initially on the suggested rat model.

\section{References}

1. Crousos GP (2000) The role of stress and hypothalamic-pituitary-adrenal axis in the pathogenesis of the metabolic syndrome: Neuroendocrine and target tissue related causes. Int J Obes Relat Metab Disord (Suppl. S) 24: 50-55.

2. Kanayama N, Khatun S, Belayet H, She L, Terao T (1999) Chronic local cold stress to the soles induces hypertension in rats. Am J Hypertens 12 (11 Pt 1), 1124-1129.

3. Marti O, Armario A (1998) Anterior pituitary response to stress: Time-related changes and adaptation. Intern J Develop Neurosci 16: 241-260.

4. Dal-Zotto S, Marti O, Armirio A (2002) Is repeated exposure to immobilization needed to induce adaptation of the hppothalamic-pituitary-adrenal axis? Influence of adrenal factors. Behav Brain Res 129: 187195.

5. Richard F, Faucon-Biguet N, Labatut R, Rollet D, Mallet J, Buda M (1988) Modulation of tyrosine hydroxylase gene expression in rat brain and adrenals by exposure to cold. J Neurosci Res 20: 32-37.

6. Baruchin A, Weisberg EP, Miner LL, Ennis D, Nisenbaum LK, Noylor E, Stricker EM, Zigmond MJ, Kaplan BB (1990) Effects of cold exposure on rat adrenal tyrosine hydroxylase: An analysis of RNA, protein, enzyme activity, and cofactor levels. J Neurochem 54: 1769-1775.
7. Nagatsu T, Levitt M, Udenfriend S (1964) Tyrosine hydroxylase: the initial step in norepinephrine biosynthesis. J Biol Chem 239: 2910-2917.

8. Sakata J, Shimokubo T, Kitamura K, Nishizono M, Lehiki Y, Kangawa K, Matsuo H, Eto T (1994) Distribution and charecterization of immunoreactive rat adrenomedullin in tissue and plasma. FEBS Letters 352: 105-108.

9. Asada Y, Hara S, Marutsuka K, Kitamura K, Tsuji T, Sakata J, Sato Y, Kisanuki A, Eto T, Sumiyoshi A (1999) Novel distribution of adrenomedullin-immunoreactive cells in human tissues. Histochem Cell Biol 112, 185-191.

10. Satoh F, Takahashi K, Murakami O, Totsune K, Sone M, Ohneda M, Sasano H, Mouri T (1996) Immunocytochemical localization of adrenomedullin-like immunoreactivity in the human hypothalamus and the adrenal gland. Neurosci Let 203: 207-210.

11. Ueta Y, Serino R, Shibuya I, Kitamura K, Kangawa K, Russell JA, Yamashita H (2000) A physiological role for adrenomedullin in rats; a potent hypotensive peptide in the hypothalamo-neurohypophysial system. Exp Physiol 85, 163-169.

12. Renshaw D, Thomson LM, Michael GJ, Carroll M, Kapas S, Hinson JP (2000) Adrenomedullin receptor in found exclusively in noradrenaline-secreting cells of the rat adrenal medulla. J Neurochem 74: 1766-1772. 
13. Hinson JP, Kapas S, Smith DM (2000) Adrenomedullin, a multifunctional regulatory peptide. Endocr Rev 21: $138-167$.

14. Evereklioglu C, Doganay S, Er H, Yurekli M (2002) Aqueous humor adrenomedullin levels differ in patients with different types of glaucoma. Jpn J Ophthalmol 46: 203-208.

15. Evereklioglu C, Ozbek E, Er H, Cekmen M, Yurekli M (2002) Urinary adrenomedullin levels are increased and correlated with plasma concentrations in patients with Behcet's syndrome. Int J Urol 9: 296, 303.

16. Savas HA, Herken H, Yurekli M, Uz E, Tutkun H, Zoroglu SS, Ozen ME, Cengiz B, Akyol O (2002) Possible role of nitric oxide and adrenomedullin in bipolar affective disorder. Neuropsychobiology 45: 5761.

17. Wimalawansa SJ (1997) Amylin, calcitonin gene-related peptide, calcitonin, and adrenomedullin: a peptide superfamily. Crit Rev Neurobiol 11: 167-239.

18. Sata M, Kakoki M, Nagata D, Nimatsu H, Suzuki E, Aoyagi T, Sugiura S, Kojima H, Nagano T, Kangawa K, Matsuo H, Omata M, Nagai R, Hirata Y (2000) Adrenomedullin and nitric oxide inhibit human endothelial cell apoptosis via a cyclic GMP-independent mechanism. Hypertension 36: 83-88.

19. Oliver KR, Kane SA, Salvatore CA, Mallee JJ, Kinse AM, Kablan KS (2001) Clonning-charecterization and central nervous system distribution of receptor activity modifying proteins in the rat. Eur J Neurosci 14: 618628.

20. Parkes DG, May CN (1995) ACTH-suppressive and vasodilator actions of adrenomedullin in conscious sheep. J Neuroendocrinol 7: 923-929.

21. Yamaguchi T, Baba K, Doi Y, Yano K (1995) Effect of adrenomedullin on aldosterone secretion by dispersed rat adrenal zona glomerulosa cells. Life Sci 56: 379 387.

22. Albertin G, Malendowicz LK, Tortorella C, Mazzocchi G, Nussdorfer GG (2000) Evidence for a paracrine role of adrenomedullin in the physiological resetting of aldosterone secretion by rat adrenal zona glomerulosa. Peptides 21: 413-417.

23. Andreis PG, Mazzocchi G, Rebuffat P, Nussdorfer GG (1997). Effects of adrenomedullin and proadrenomedullin N-terminal 20 peptide on rat zona glomerulosa cells. Life Sci 60: 1693-1697.

24. Hinson JP, Thomson LM, Kapas S (1998) Adrenomedullin and CGRP receptors mediate different effects in the adrenal cortex. Endocr Res 24: 725-728.

25. Katoh F, Niina H, Kitamura K, Ichiki Y, Yamamoto Y, Kangawa K (1994) $\mathrm{Ca}^{2+}$ dependent cosecretion of adrenomedullin in catecholamines mediated by nicotinic receptors in bovine cultured medullary cells. FEBS Let 348: 61-64.

26. Katoh F, Kitamura K, Niina H, Yamamoto R,
Washimine H, Kangawa K, Yamamoto Y, Kobayashi H, Eto T, Wada A (1995) Proadrenomedullin Nterminal 20-peptide, an endogenous anticholinergic peptide: its exocytotic secretion and inhibition of chatecholamine secretion in adrenal medulla. J Neurochem 64: 459-461.

27. Champion HC, Fry RC, Murphy WA, Coy DH, Kadowitz PJ (1996) Catecholamine release mediates pressor effects of adrenomedullin-(15-22) in the rat. Hypertension 28: 1041-1046.

28. Sone M, Takahashi K, Satoh F, Murakami O, Totsune K, Ohneda M, sasano H, Ito H, Mouri T (1997) Specific adrenomedullin binding sites in the human brain. Peptides 18: 1125-1129.

29. Shan J, Krukoff L (2001) Distribution of preproadrenomedullin mRNA in the rat central nervous system and its modulation by physiologic stressors. J Comp Neurol 26: 432, 88-100.

30. Takekoshi K, Isobe K, Nomura F, Motooka M, Nanmoku T, Nakai T (1999) Effects of PAMP on mRNAs coding for catecholamine-synthesizing enzymes in PC12 cells. Life Sci 65: 771-781.

31. Sun JR, Ma YC, Xu ZH, Zhao WJ, Cai YP (1997) Effect of norepinephrine on the thermosensitive neurons in preoptic area of hypoyhalamus tissue lices in cold acclimatized rats. Sheng Li Hsueh Pao 49: 660-670.

32. Fregly MJ, Rossi F, Sun Z, Tumer N, Cade JB, Hegland D, Yurekli M (1994) Effect of chronic treatment with prazosin and L-arginine on the elevation of blood pressure during cold exposure. Pharmacology 49: 351-362.

33. Bradford MM (1976) A rapid and sensitive method for the quantition of microgram quantities of protein utilizing the principle of protein dye binding. Anal Biochem 72: 248-254.

34. Reinhard JF, Gary K, Smith and Charles AN (1986) A rapid and sensitive assay for tyrosine 3-monooxygenase based upon the release of ${ }^{3} \mathrm{H}_{2} \mathrm{O}$ and adsorbtion of ${ }^{3}(\mathrm{H})$-tyrosine by chorcoal. Life Sci 39: 2185-2189.

35. Kato T, Bishop AT, Tu YK, Wood MB (1998) Function of the vascular endothelium after hypothermic storage at $4^{\circ} \mathrm{C}$ in a canine tibial perfusion model. The role of adrenomedullin in reperfusion injury. $J$ Bone Joint Surg Am 80: 1341-1348.

36. Ceyhan BB, Karakurt S, Hekim N (2001) Plasma adrenomedullin levels in asthmatic patients. J Asthma 38: $221-227$.

37. Kapas S, Hinson JP (2002) Adrenomedullin in the adrenal. Microscopy Res Tech 57: 91-97.

38. Masada K, Nagayama T, Hosokawa A, Yoshida M, Suzuki KM, Hisa II, Kimura T, Satoh S (1999) Effects of adrenomedullin and PAMP on adrenal catecholamine release in dogs. Am J Physiol 276 (4Pt 2): 1118-1124.

39. Okamura T, Zhang JX, Kangawa K, Toda N (1997) 
Inhibition by Adrenomedullin of the adrenerjic neurogenic response in canine mesenteric arteries. Jpn $J$ Pharmacol 73: 259-261.

40. Garcia A, Marti O, Valles A, Dal-Zotto S, Armirio A (2000) Recovery of the hypothalamic-pituitary-adrenal response to stress-effect of stress intensity, stress duration and previous stress exposure. Neuroendocrinology 72: 114-125.

41. Nussdorfer GG, Rossi GP, Mazzocchi G (1997) Role of adrenomedullin and related peptides in the regulation of the hypothalamo-pituitary-adrenal axis. Peptides 18: 1079-1089.

42. Coppock HA, Owji AA, Austin C, Upton PD, Jackson MD, Gardiner JV, Ghatci MA, Bloom SR, Smith DM
(1999) Rat-2 fibroblasts express specific adrenomedullin reseptors, but not calcitonin-gene-related-peptidereceptors, which mediate increased intracellular cAMP and inhibit mitogen activated protein kinase activity. Biochem J 338 (Pt 1): 15-22.

43. Mishima K, Kato J, Kusawasaka K, Ito K, Imamura T, Kitamura K, Eto T (2001) Effects of endothelin on adrenomedullin secretion and expression of adrenomedullin receptors in rat cardiomyocytes. Biochem Res Commun 287: 264-269.

44. Edwards RM, Stack EJ, Trizma W (1991) Calcitonin gene-related peptide stimulates adenylate cyclase and relaxes intracerebral arterioles. J Pharmacol Exp Ther 257: 1021-1024. 